\title{
Vitamin D, zinc and glutamine: Synergistic action with OncoTherad immunomodulator in interferon signaling and COVID-19 (Review)
}

\author{
JOSÉ JOÃO NAME ${ }^{1}$, ANDREA RODRIGUES VASCONCELOS ${ }^{2}$, \\ ANA CAROLINA REMONDI SOUZA ${ }^{1}$ and WAGNER JOSÉ FÁVARO 3 \\ ${ }^{1}$ Kilyos Assessoria, Cursos e Palestras (Kilyos Nutrition), São Paulo, SP 01311-100; \\ ${ }^{2}$ Department of Pharmacology, Institute of Biomedical Sciences, University of Sao Paulo, Sao Paulo, SP 05508-000; \\ ${ }^{3}$ Laboratory of Urogenital Carcinogenesis and Immunotherapy, University of Campinas, Campinas, SP 13083-970, Brazil
}

Received August 16, 2020; Accepted November 16, 2020

DOI: $10.3892 /$ ijmm.2021.4844

\begin{abstract}
Coronavirus disease 2019 (COVID-19), caused by severe acute respiratory syndrome coronavirus 2 (SARS-CoV-2), was identified in December, 2019 in Wuhan, China. Since then, it has continued to spread rapidly in numerous countries, while the search for effective therapeutic options persists. Coronaviruses, including SARS-CoV-2, are known to suppress and evade the antiviral responses of the host organism mediated by interferon (IFN), a family of cytokines that plays an important role in antiviral defenses associated with innate immunity, and has been used therapeutically for chronic viral diseases and cancer. On the other hand, OncoTherad, a safe and effective immunotherapeutic agent in the treatment of non-muscle invasive bladder cancer (NMIBC), increases IFN signaling and has been shown to be a promising therapeutic approach for COVID-19 in a case report that described the rapid recovery of a 78-year-old patient with NMIBC with comorbidities. The present review discusses the possible synergistic action of OncoTherad with vitamin D, zinc and glutamine, nutrients that have been shown to facilitate immune responses mediated by IFN signaling, as well as the potential of this combination as a therapeutic option for COVID-19.
\end{abstract}

\section{Contents}

1. Introduction

2. Zinc

3. Vitamin D

4. Glutamine

5. Conclusion

Correspondence to: Dr José João Name, Kilyos Assessoria, Cursos e Palestras (Kilyos Nutrition), Avenida Paulista, 777-conjunto 11, Bela Vista, São Paulo, SP 01311-100, Brazil

E-mail: namepucsp@gmail.com

Key words: OncoTherad, vitamin D, zinc, glutamine, interferon, Coronavirus disease 2019, severe acute respiratory syndrome coronavirus 2 , immunity

\section{Introduction}

Coronavirus disease 2019 (COVID-19) is caused by a novel coronavirus: Severe acute respiratory syndrome coronavirus 2 (SARS-CoV-2) (1,2). After the first case of COVID-19 was diagnosed in the city of Wuhan, China, in December, 2019, the disease spread rapidly and was declared a pandemic by the World Health Organization (WHO) on March 11, 2020 (3). As the COVID-19 outbreak advances worldwide, there is a growing need to identify strategies with which to combat the virus.

Briefly, the cell entry of SARS-CoV-2 occurs after its spike (S) proteins bind to the human angiotensin-converting enzyme 2 (ACE2) receptor, which is expressed in several cell types, such as lung alveolar and nasal epithelial cells, enterocytes and vascular endothelial cells $(4,5)$. After binding ACE2, the $\mathrm{S}$ proteins are cleaved by SARS-CoV-2 entry-activating proteases from the host cell, including type II transmembrane protease serine 2 (TMPRSS2), exposing fusion peptide domains in a process termed $\mathrm{S}$ protein priming. Once membrane fusion occurs, the SARS-CoV-2 RNA genome is released into the host cell, triggering viral replication and pathogenic events $(4,5)$.

Some nutrients have the ability to modulate the innate and acquired immune systems, and play important roles in antiviral resistance. The finding of possible synergistic actions between nutrients, as well as between nutrients and drugs, may allow the development of complex formulations that act differently from the individual components. In this context, certain specific nutrients, namely zinc, vitamin D and glutamine have been considered. These nutrients are referenced as potential adjuvants in the prevention and treatment of viral infections (6-9). Moreover, emerging evidence provided in the literature has consistently highlighted the potential role of these nutrients, as well as the immunotherapeutic agent OncoTherad, in the prevention or therapy of COVID-19 (10-27). The combination of these nutrients with OncoTherad aims to provide specific metabolic support that, when coordinated with their individual antiviral effects, may represent a putative therapeutic and/or preventive action against COVID-19. 
A common mechanism among these compounds, which already exhibit an important synergy, is their ability to modulate the signaling pathways for interferons (IFNs), which are cytokines recognized for their antiviral properties $(8,28-35)$. This area of metabolic confluence, dependent on these nutrients, also corresponds to a synthetic nanocompound known as OncoTherad, developed as an antineoplastic and immunomodulator used as therapy for non-muscle invasive bladder cancer (NMIBC) (36-38). With the objective of designing a joint use, considering a possible enhancement of their efficiencies, the present review article discusses the common properties of these compounds (zinc, vitamin D, glutamine and OncoTherad), considering that when a deficiency occurs, nutrients may become limiting factors of the action of other nutrients and drugs (39).

Toll-like receptor (TLR) and interferon signaling pathways. Once cells are infected by a virus, viral pathogen-associated molecular patterns (PAMPs) can be recognized by several intracellular pathogen recognition receptors (PRRs), such as TLRs. For example, TLR2, TLR3, TLR4, TLR7, TLR8 and TLR9 play important roles in the recognition and detection of nucleic acids (RNA and DNA) specific to the viral genome (40). Some viruses can avoid recognition by TLRs and may be recognized by other intracellular PRRs present in the cytosol (40).

Despite the different types of PRRs that can be activated, the antiviral immune response following the PAMP-PRR interaction involves common signaling pathways. In general, the recognition of viral pathogens is associated with the production of several inflammatory cytokines, in particular IFNs, that have important antiviral and anti-proliferative activity (40).

IFNs are a group of cytokines secreted by infected or immune cells that perform critical functions in the immune system, such as the activation of natural killer (NK) cells and macrophages (40). These cytokines are the first line of defense against viral infections. The binding of IFNs to their cell surface receptors leads to the activation of the Janus-activated kinase (JAK)/signal transducer and activator of transcription (STAT) signaling pathway, which induces the expression of several genes that fight viral replication in the cell itself and in neighboring cells $(28,41)$. Type I IFNs include IFN- $\alpha$ and IFN- $\beta$, while the type II IFN class has IFN- $\gamma$ as its only member (42). In turn, type III IFN (IFN- $\lambda$ ) is a recently discovered distinct class that, despite activating a complex of different receptors, activates the same JAK/STAT signaling pathway (43).

In addition to the key role in antiviral immune responses, IFNs may also exert anti-inflammatory effects associated with the inhibition of the production of pro-inflammatory cytokines, such as interleukin (IL)-1, IL-18 and IL-12 and/or increasing the production of the anti-inflammatory cytokine IL-10 (44-49). Although a rapid and effective immune response is essential to limit viral spread, this antiviral response needs to be controlled to limit tissue damage. It is known that excessively high levels of serum pro-inflammatory cytokines and chemokines (cytokine storm) produce an uncontrolled systemic inflammatory response that contributes to the increased severity of viral infections, such as those caused by SARS-CoV-2, influenza virus, Middle East respiratory syndrome coronavirus (MERS-CoV) and severe acute respiratory syndrome coronavirus (SARS-CoV). This is one of the major mechanisms responsible for acute respiratory distress syndrome (ARDS), the primary cause of mortality from COVID-19 (49-55). Thus, IFNs can play a role in the treatment of COVID-19, not only through their antiviral activity, but also by counterbalancing the cytokine storm, which is actually observed in acute infection by the influenza A virus (49). Other mechanisms through which these compounds could potentially counteract the cytokine storm, specifically related to their well-known immunomodulatory effects, and other aspects of COVID-19 not covered in the present review are further discussed elsewhere $(11,13,15,16,19-21,23,25,26)$.

Although the mechanisms of SARS-CoV-2 are not yet well known, its genetic (approximately 79\%) and structural similarity with SARS-CoV, as well as the similar pathogenic mechanism of cell entry via interaction with ACE2, and the comparable pattern of mortality by age group suggest that previous findings on SARS may be partially applicable to COVID-19 $(56,57)$. In SARS, there are abnormally low levels of antiviral cytokines, particularly type I IFNs (58). In addition, in severe respiratory diseases caused by the coronavirus subtypes SARS-CoV and MERS-CoV, the reaction to viral infections by type I IFNs is suppressed. Both types of coronaviruses use varying strategies to evade the antiviral defense system of IFNs, such as inhibition of the production of type I IFN by infected cells, interference in the IFN signaling pathway and increased resistance to IFNs. These suppression approaches are highly associated with disease severity and an increased mortality (58-60).

In fact, it has been observed that the reduction in IFN- $\gamma$ expression in $\mathrm{CD}^{+} \mathrm{T}$ cells is related to disease severity in patients with COVID-19 (61). A recent study that used ex vivo human lung tissue samples found that SARS-CoV-2, although replicating and infecting more efficiently than SARS-CoV, did not lead to the expression of type I, II or III IFNs (62).

The use of IFNs for the treatment of viral infectious diseases has been shown to be effective (63). For example, type I IFNs are part of the standard treatment for chronic infections by hepatitis B and C viruses (63). Numerous studies have also reported the success of the direct administration of IFNs against coronavirus (64-72). It has been shown that a combination of type I IFN and IFN- $\gamma$ synergistically inhibits viral replication in vitro (73-76). Thus, the induction of IFNs has immense potential in the defense of organisms against coronavirus infections. Several clinical trials are currently underway to investigate the efficacy of IFN treatments in patients with COVID-19 (NCT04385095, NCT04350671, NCT04465695, NCT04534673,NCT04480138,NCT04492475,NCT04354259, NCT04494399, NCT04254874, NCT04324463, NCT04315948, NCT04344600, NCT04276688, ChiCTR2000029387 and ChiCTR2000029600), including cancer patients (NCT04379518, NCT04534725) (77).

OncoTherad. The synthetic nanocompound, Biological Response Modifier - Inorganic Phosphate Complex 1 (MRB-CFI-1, for its acronym in Portuguese), registered as OncoTherad, is a nanometric compound of metallic salts and phosphate and associated with a glycosidic protein, 
$420-530 \mathrm{~nm}$ in size (36-38,78-80). This novel nano-immunotherapy stimulates the immune system to eliminate cancer and could become a promising strategy against SARS-CoV-2. The immunotherapy drug is being developed by researchers at the University of Campinas in the state of São Paulo, Brazil, and has patents deposited in Brazil (no. BR1020170127680) (38), USA (no. US20200156951A1) (80) and Europe (no. WO2018227261) (81). It is being tested in clinical trial (Brazilian Clinical Trials Registry -RBR-6swqd2, UTN U1111-1226-9096) and is still not available on the market.

OncoTherad is a novel intravesical therapy with immunological and antitumor properties for the treatment of NMIBC. The primary treatment for NMIBC is based on surgical transurethral resection followed by intravesical immunotherapy with bacillus Calmette-Guérin (BCG) to avoid tumor progression and decrease recurrence. Preclinical, clinical-veterinary and phase I/II clinical trials have shown that nano-immunotherapy with OncoTherad leads to the distinct stimulation of the innate immune system mediated by TLR 2 and TLR4, resulting in an increased activation of the IFN signaling pathway [TLR4, TIR-domain-containing adapter-inducing IFN- $\beta$ (TRIF), interferon regulatory factor (IRF)-3, IFN- $\alpha$ and $-\gamma]$, which is associated to the superior efficacy of this nanocompound in the management of NMIBC compared to the standard treatment with BCG $(36-38,82)$.

More specifically, the OncoTherad-induced stimulation of the immune system via TLR2 and TLR4 occurs through the phosphorylation of hydroxylated amino acids, such as tyrosine, threonine and serine by compounds that contain phosphate salts (36-38,78-80), resulting in the activation of stimulator of interferon genes (STING), with a consequent increase in the production of IFN- $\alpha$ and IFN- $\gamma$. The increase in the production of IFNs mediated by TLRs- 2 and 4 promotes the activation of $\mathrm{TCD} 8^{+}$cells, dendritic cells and M1 macrophages, culminating in the superior effectiveness of OncoTherad in the therapy of bladder cancer when compared to BCG $(37,38,78,80)$. Experiments with rodents $(36,38,80)$ and $\operatorname{dogs}(38,79,80)$ have demonstrated that OncoTherad is able to decrease the expression of receptor activator of nuclear factor- $\mathrm{KB}$ (RANK) and receptor activator of nuclear factor- $\mathrm{kB}$ ligand (RANK-L) system and, as a result, prevent the formation of metastases and/or counteract their progression. In addition, in the treatment of bladder cancer chemically induced in Fisher 344 rats, OncoTherad nano-immunotherapy was shown to increase the immunoreactivities of regulatory proteins, such as phosphatase and tensin homolog (PTEN) and p21, demonstrating the positive contribution of this immunotherapy in the regulation of the cell cycle (80).

A previous study demonstrated that the stimulation of TLR4 resulted in protective immune response and TRIF-related adaptor molecule (TRAM) knockout mice were more susceptible to coronavirus infection and expressed molecular signs similar to those of SARS-CoV and MERS-CoV with a poor prognosis (83). Furthermore, SARS-CoV may interfere on IRF-3 signaling, delaying IFN activity (60). Therefore, considering the immunomodulation promoted by OncoTherad and the role of the IFN signaling pathway in the control of COVID-19, this compound emerges as a promising therapeutic option for SARS-CoV-2 infection control and reduction of lung injury severity.
In 5 patients who developed severe COVID-19 while undergoing treatment for NMIBC, the administration of OncoTherad with corticosteroids and antibiotics mitigated the exacerbated inflammatory response in the lungs, decreased the average hospital stay from 18 to 10 days, and prevented the need for intubation $(17,84)$.

A 78-year-old Brazilian male enrolled on the OncoTherad clinical trial (Brazilian Clinical Trials Registry-RBR-6swqd2) for the treatment of BCG-refractory or relapsed NMIBC was the most emblematic case. The patient with a history of former tabagism (34 years), systemic arterial hypertension and previous revascularization of myocardium, arrived at the Hospital Municipal de Paulinia in Brazil, presenting with COVID-19 symptoms (84). He reported a dry cough, inappetence, coryza and malaise, which appeared immediately following a cruise trip. The diagnosis of SARS-CoV-2 was confirmed with local RT-PCR, IgM/IgG serological rapid screening and a chest CT scan (84).

Before exhibiting symptoms of COVID-19, the patient was diagnosed with high-grade papillary urothelial carcinoma. In January, 2020, due to a refractory tumor, the patient was enrolled in the OncoTherad clinical trial, developed at the University of Campinas. Consecutive weekly applications of OncoTherad (one intravesical and one intramuscularly applied per week, for 4 weeks) were used to treat the cancer before the patient interrupted the treatment for 2 weeks for travel purposes. On April 1, 2020, following $24 \mathrm{~h}$ of having flu-like symptoms, the patient's clinical condition evolved to fever $\left(38.3^{\circ} \mathrm{C}\right)$, headache, dyspnea $\left(\mathrm{pO}_{2}, 66.4 \mathrm{mmHg} ; \mathrm{SatO}_{2}, 87 \%\right.$; respiratory frequency, $21 \mathrm{bpm}$ ) and basilar crackling and stertors in the lungs. A chest CT scan revealed areas of ground-glass opacities on lung parenchyma with bilateral distribution and predominance on right upper and middle lobes, pointing to an evolving acute lung inflammatory process (84).

OncoTherad immunotherapy was resumed to treat the cancer condition with one intramuscular application. The COVID-19 treatment regimen included oxygen therapy (nasal catheter flux 4 liters/min), Ceftriaxone $2 \mathrm{~g}$ (for 6 days, intravenously), Azithromycin $500 \mathrm{mg}$ (for 6 days, intravenously) and Tamiflu $75 \mathrm{mg}$ [twice a day (b.i.d.), for 5 days, orally]. At $72 \mathrm{~h}$ following hospitalization, the symptoms of coryza and cough improved, with the absence of fever. However, the patient presented continued inappetence and fatigue on minimal exertions. Oxygen therapy was maintained, and, after 6 days of hospitalization, the patient exhibited a significant improvement in pulmonary inflammation ( $\mathrm{SatO}_{2}, 94 \%$ at room air), with the withdrawal of oxygen therapy and significant clinical improvement on the 8th day $\left(\mathrm{pO}_{2}, 96.2 \mathrm{mmHg} ; \mathrm{SatO}_{2}, 98 \%\right.$; decreased basilar crackling and stertors in the lungs, absence of fever, attenuated cough and appetite enhancement). The patient was discharged in a good general condition on the 10th day of hospitalization (84). Patient progression and recovery occurred in a shorter time period (10 days) than reported in a previous study (85). As previously demonstrated, $86 \%$ of patients enrolled in a Chinese study were discharged after 16 days of hospitalization; the majority of individuals exhibited radiological worsening on the 7th day and improvement on the 14th day (85).

A new chest $\mathrm{CT}$ scan was performed on patient discharge and a comparative analysis with the chest $\mathrm{CT}$ acquired upon admission revealed areas of periphery pulmonary consolidations 
and fibrous stripes. Areas of ground-glass opacities were no longer observed. Moreover, treatment-related adverse events were Grade 1 or 2, such as pruritus and rash (84).

In addition, as regards the case report of immunotherapy with OncoTherad, Delafiori et al (84) identified 33 molecules related to the metabolic state at admission and 39 after improvement of the clinical condition and discharge. The authors revealed extensive lipid dysregulation with marked disturbances in the metabolism of glycerophospholipids, glycerolipids, lipid sterols and fatty acids. Several fatty acids species were identified in that study under admission and discharge conditions, including mediators of linoleic and arachidonic acid metabolism, which play a crucial role in the response to inflammation (84).

Notably, the other 4 patients subjected to the clinical protocol of OncoTherad therapy for NMIBC who tested positive for COVID-19 exhibited a similar outcome to that of the patient described in the aforementioned case report. Their recovery was more rapid (10 days) when compared to the observed for patients subjected to the standard treatment only (17).

Considering the comorbidities and age of the patients, it is considered that immunotherapy with OncoTherad exerted a protective effect in this patient, preventing the progression of infection to the most severe states and promoting fast recovery without the need for admission to the intensive care unit (84). A study with 140 participants for the use of OncoTherad immunotherapy associated with standard clinical treatment for COVID-19 is underway at Hospital Municipal de Paulinia. The study is expected to last for 1 year (17).

Studies have indicated that some nutrients, particularly zinc, vitamin D and glutamine, play an important role in the immune system and also modulate the IFN signaling pathway, as described below, which may suggest a possible synergistic action with OncoTherad.

\section{Zinc}

Several studies have indicated the antiviral activity of zinc against several viruses, such as SARS-CoV, rhinovirus, influenza, herpes virus, respiratory syncytial virus, equine arteritis virus, hepatitis $\mathrm{E}$ virus and transmissible gastroenteritis virus $(6,86-90)$. For example, zinc has been shown to inhibit viral RNA polymerase activity in vitro and viral replication in Vero-E6 cells infected with SARS-CoV (89). The antiviral mechanisms of action of zinc include the modulation of the immune system of the infected individual, with increased signaling associated with IFNs. These cytokines also stimulate the influx of zinc into the target cell, which highlights the importance of this element for IFN signaling (6).

Zinc induces the production of IFN- $\alpha$ and IFN- $\gamma$, and enhances the antiviral action of IFN- $\alpha$ (29-31). A previous study found that zinc and its transporter, ZIP8 (SLC39A8), regulated the expression of IFN- $\gamma$ in activated human $\mathrm{T}$ lymphocytes, which was confirmed by increased IFN- $\gamma$ release with ZIP8 overexpression and reduced release of the cytokine with a reduction in the expression (knockout) of this zinc transporter (91). The same study demonstrated an increase in the production of IFN- $\gamma$ in vitro by activated T lymphocytes isolated from individuals supplemented with $15 \mathrm{mg} /$ day zinc orally and an even greater increase after the treatment of activated $\mathrm{T}$ lymphocytes with zinc in vitro (91).

In turn, in human primary lung cells, in the absence of zinc, treatment with IFN- $\gamma$ and tumor necrosis factor (TNF)- $\alpha$ and the activation of Fas receptor signaling may result in cell death by apoptosis and dysfunction of the pulmonary epithelial barrier, indicating that zinc is a vital factor in the protection of this epithelium against acute damage (92).

STAT1 is a key mediator of the IFN signaling pathway. Reduced zinc bioavailability by the zinc chelating agent, $\mathrm{N}, \mathrm{N}, \mathrm{N}$,, $\mathrm{N}^{\prime}$-tetrakis(2-pyridylmethyl)ethylenediamine (TPEN), has been shown to significantly reduce the gene expression and protein level of STAT1 in macrophages, which may be associated with increased susceptibility to infections in zinc deficiency (93). By contrast, increased zinc concentrations may restrict the replication of hepatitis $\mathrm{E}$ virus, increasing the level and activity of STAT1 and/or inducing the antiviral response mediated by IFN-stimulated genes via a mechanism mediated by the nuclear transcription factor- $\kappa \mathrm{B}(\mathrm{NF}-\kappa \mathrm{B})(90)$.

Interferon-induced transmembrane proteins (IFITMs) are known for their antiviral functions. They are crucial for the IFN-mediated inhibition of a number of enveloped viruses, including influenza A and Ebola virus (94). Similarly, the zinc metalloprotease, ZMPSTE24, exhibits antiviral activity against several enveloped viruses, including those already mentioned $(95,96)$. Both the IFITM 3 and ZMPSTE24 proteins are induced by IFN (90), which in turn is induced by zinc treatment. Given that SARS-CoV-2 is an enveloped virus, it is assumed that the increase in IFITM and/or ZMPSTE24 induced by zinc could be effective in exerting antiviral effects against COVID-19.

Zinc also acts as an important mediator of the signaling of several immune cell receptors (97). One of these is the TLR4 receptor, which, similar to other TLR receptors, plays an important role in virus recognition and antiviral immune response $(40,97)$. Upon activation, TLR4 binds to the adaptor protein MyD88 and causes an increase in cytoplasmic levels of free zinc $\left(\mathrm{Zn}^{2+}\right)$. This zinc signaling is necessary for the activation of MyD88-dependent NF- $\mathrm{kB}$, resulting in the expression of genes targeting this transcription factor, such as the inflammatory cytokines TNF- $\alpha$, IL- $1 \beta$ and IL- 6 (97). These cytokines perform several important functions in the adaptive immune response, contributing to antiviral defense (98).

Clinical studies. A clinical study with 21 healthy elderly individuals in Italy (mean age, 87 years) found that the consumption of zinc-fortified milk ( $3 \mathrm{mg}$ of added zinc plus $1 \mathrm{mg}$ of zinc naturally present in milk) for 2 months, compared to the consumption of non-fortified milk, increased cellular immunity, which was concluded by the increased release of the cytokines, IFN- $\gamma$ and IL-12p70, and increased endocrine activity in the thymus (active thymulin, linked to zinc) (99). In that study, peripheral blood mononuclear cells (PBMCs) isolated from the elderly individuals who consumed zinc-fortified milk following inflammatory stimulation with lipopolysaccharide (LPS) exhibited a significant increase of $25.7 \%$ in the release of IFN- $\gamma$, indicating better cellular immune functioning (99).

These data are in agreement with those of a study on 19 healthy elderly individuals supplemented with $10 \mathrm{mg}$ of 
elemental zinc (50 $\mathrm{mg}$ of zinc aspartate). PBMCs isolated from the elderly individuals and stimulated with SPEA in vitro were evaluated before and after zinc supplementation. Supplementation led to a significant increase in the release of the pro-inflammatory cytokines, IFN- $\gamma$ (53.28\%) and TNF- $\alpha(80.03 \%)(\mathrm{P}<0.006)$, and the anti-inflammatory cytokine, IL-10 (31.79\%) $(\mathrm{P}<0.003)$. These results indicated that zinc supplementation led to an improvement in the immune response of $\mathrm{T}$ lymphocytes (100).

\section{Vitamin D}

Despite the traditional name, vitamin D is actually a hormone, as in addition to being endogenously produced, it is in involved in the regulation of $>200$ genes in different cell types (101-103). Vitamin D is converted into its active form (calcitriol) through the action of the enzyme $1 \alpha$-hydroxylase (CYP27B1). The detection of the expression of this enzyme and of vitamin D receptors in immune cells and the observation that the expression of these receptors is regulated by immune signaling provide evidence of the central role played by vitamin D in the immune system, as well as the clear association between low serum levels of $25(\mathrm{OH}) \mathrm{D} 3$ and autoimmune diseases, cancer, cardiovascular diseases and respiratory infections (40). Respiratory epithelial cells constitutively express CYP27B1, underscoring their local need for active vitamin $\mathrm{D}(7)$.

Several studies have suggested an important antiviral role of vitamin $\mathrm{D}$, although the mechanisms are complex and remain poorly understood (7). The activation of TLRs by PAMPs in immune cells leads to the increased expression of the vitamin D receptor and of CYP27B1, increasing the conversion of circulating vitamin $\mathrm{D}$ into its active form. Thus, the metabolism of vitamin D in these cells is linked to the recognition of pathogens, rendering it an integral part of the innate immune response $(40,104)$.

For example, the activation of TLR4 by LPS has been shown to lead to the increased expression of CYP27B1 in monocytes $(105,106)$. Similarly, in dendritic cells, the activation of TLR4 or TLR3 induces the expression of CYP27B1, altering the migratory properties of these cells to allow the presentation of antigens to $\mathrm{CD}^{+} \mathrm{T}$ lymphocytes (107-110). In human tracheobronchial epithelial cells, TLR stimulation by poly I:C and live respiratory syncytial virus increases the expression of CYP27B1, resulting in the increased conversion of vitamin D into its active form (calcitriol) and the increased expression of cathelicidins, antimicrobial peptides with important antiviral action (111). Similar effects have been reported for TLR8 and TLR2/1 heterodimer (40).

The cytokines, IFN- $\gamma$, IL-13, IL-15, IL-4, IL-1, IL-2 and TNF- $\alpha$, also regulate the expression of CYP27B1 and vitamin $\mathrm{D}$ metabolism. The signaling pathways involved in this process are probably the same as those involved in regulation induced by the activation of TLRs $(40,112)$.

Vitamin D is necessary for the antimicrobial immune response of human macrophages mediated by IFN- $\gamma$ production against Mycobacterium tuberculosis as this antimicrobial response was not observed with macrophages cultured in human serum of individuals with insufficient levels of this hormone. It has been suggested that increased serum levels of vitamin D may improve the IFN- $\gamma$-mediated antimicrobial immune response of human macrophages (32).

In summary, the studies mentioned above indicate that the extrarenal synthesis of calcitriol is regulated by TLR activation and cytokine secretion. Thus, in the presence of sufficient levels of circulating vitamin $\mathrm{D}$, infection by respiratory viruses, which results in recognition by TLRs and cytokine production, is able to increase calcitriol levels, possibly altering the immune response to optimize the fight against these pathogens (40).

Importantly, as previously mentioned, SARS-CoV-2 binds to ACE2 for host cell entry. Given that it acts as the viral receptor, it would be reasonable to hypothesize that the higher expression of ACE2 may be detrimental for the host (113). However, several lines of evidence indicate that ACE2 plays a critical role in counteracting ARDS and acute lung injury (113-116). In fact, the viral binding reduces ACE2 activity, which in turn increases ACE1 activity due to the disruption of the ACE2/ACE1 activity ratio, causing elevated pulmonary vasoconstriction and contributing to the severity of COVID-19 (117,118). Vitamin D has been shown to increase the expression of ACE2 in the lungs, which prevents the pulmonary vasoconstriction response in COVID-19 cases and can reduce lung injury. In this context, targeting ACE2 downregulation with vitamin D in SARS-CoV-2 infection may be a potential therapeutic approach to COVID-19 and induced ARDS (113,117-119). Further studies are warranted to confirm this hypothesis (27).

Clinical studies. Several clinical trials have indicated that vitamin D3 supplementation (1,000 or 2,000 IU/day) is effective for enhancing the efficacy of antiviral treatment with pegylated interferon and ribavirin (PEG-IFN/RBV) in patients with hepatitis C (120-123). Conversely, low serum concentrations of the hormone seem to be related to severe hepatic fibrosis and/or to the lower responsiveness to treatment with PEG-IFN/RBV (124,125).

In a study with 50 patients with hepatitis $C$ treated with PEG-IFN/RBV, the authors reported that low serum levels of vitamin $\mathrm{D}$ were associated with negative treatment results, while supplementation with this hormone $(2,000 \mathrm{IU} /$ day for 24 weeks) significantly improved the viral response, defined as an undetectable serum level of viral RNA 24 weeks following the discontinuation of therapy (122). These results were later corroborated by a clinical trial with 84 patients with hepatitis $\mathrm{C}$ that also concluded that vitamin $\mathrm{D}$ supplementation (1,000 IU/day) from the eighth week until the end of treatment with PEG-IFN/RBV may increase the effects of antiviral therapy (123).

\section{Glutamine}

Glutamine is an amino acid used as a nitrogen source for rapidly-dividing cells, such as lymphocytes, in which it is critical for nucleotide synthesis and energy production (126).

$\mathrm{T}$ lymphocytes are activated rapidly following their interaction with pathogens, which requires high energy and biosynthetic demands (35). These augmented metabolic needs are met by increased absorption and use of glutamine, which is essential for the proliferation of these immune cells $(33,35,127)$. 

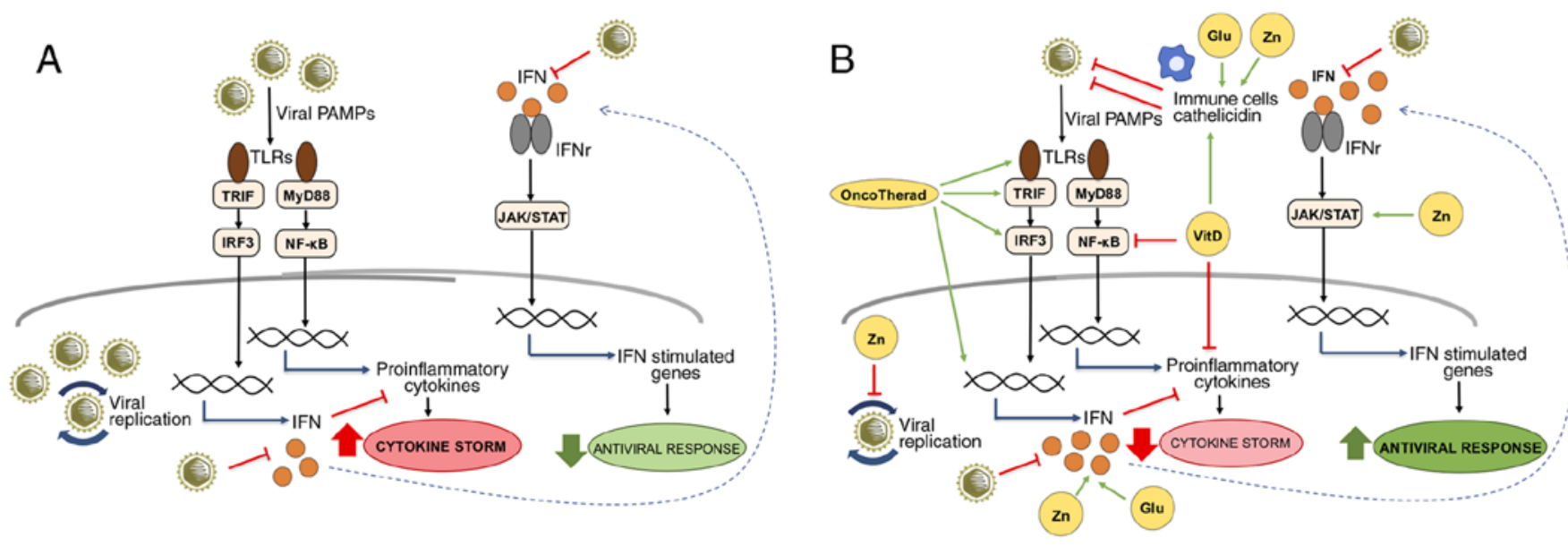

Figure 1. IFN-related signaling pathways modulated by OncoTherad, zinc, vitamin D and glutamine during viral infections. (A) Viral PAMPs are recognized by TLRs, triggering signaling pathways mediated by TRIF and MyD88. The TRIF/IRF3 pathway activates the expression of IFNs that, when interacting with their receptors, activate the JAK/STAT pathway and the expression of genes with important antiviral functions. On the other hand, the MyD88/NF- $\mathrm{kB}$ pathway is responsible for the expression of pro-inflammatory genes, such as cytokines, which, when in excess, contribute to the cytokine storm characterized by uncontrolled inflammation. SARS-CoV-2 is known for inducing cytokine storm associated with severe forms of COVID-19, as well as for inhibiting the production of IFNs and evading the IFN-related antiviral defense system. (B) The compounds OncoTherad, zinc, vitamin D and glutamine can contribute to the organism's antiviral defenses by several mechanisms: OncoTherad increases the TLR4/TRIF/IRF3/INF signaling pathway; zinc inhibits viral replication, activates STAT1, stimulates IFN production and induces the antiviral responses mediated by IFN-stimulated genes; vitamin D inhibits NF- $\mathrm{kB}$ and the expression of its pro-inflammatory target genes, as well as stimulates immune cells and the expression of catelicidin with antiviral activity; and glutamine is essential for the proliferation of immune cells and the production of IFN. Together, these compounds can help to attenuate inflammation associated with the cytokine storm and to increase the organism's antiviral status. The green arrows represent activation, the red truncated lines indicate inhibition and the blue arrows indicate activation of gene expression. Glu, glutamine; IFN, interferon; IFNr, interferon receptor; JAK/STAT, Janus-activated kinase/signal transducer

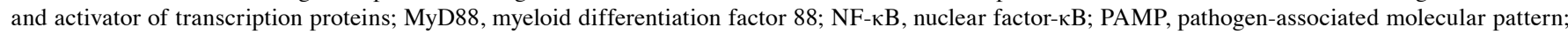
TLR, Toll-like receptor; TRIF, Toll/IL-1 receptor domain-containing adaptor inducing IFN- $\beta$; VitD, vitamin D; Zn, zinc.

In fact, the activation of naive $T$ lymphocytes is associated with the rapid glutamine uptake, which requires the amino acid transporter ASCT2 (128). Glutamine transporters are upregulated during the activation of T lymphocytes, while a reduction in these transporters impairs the function of these immune cells $(33,129)$.

Activated human $\mathrm{T}$ lymphocytes also require glutamine for the production of IFN- $\gamma$ and IL-2. This compound modulates not only the proliferation of stimulated PBMCs, but also the secretion of these cytokines in a concentration-dependent manner (130), and glutamine depletion inhibits $\mathrm{T}$ lymphocyte proliferation, and decreases IL-2 and IFN- $\gamma$ production $(33,34)$.

When a naive $\mathrm{CD} 4^{+} \mathrm{T}$ cell is activated by antigens, the types of cytokines determine whether this cell will differentiate into an effector $\mathrm{T}$ lymphocyte that performs an immune response, such as a helper T helper 1 cell (Th1) or a regulatory $\mathrm{T}$ lymphocyte, which suppresses immune responses. Even in the presence of cytokines that normally promote the generation of Th1 cells, glutamine depletion favors the regulatory $\mathrm{T}$ phenotype rather than the Th1 phenotype, which is associated with the suspension of IFN- $\gamma$ secretion (35). Thus, reduced glutamine availability alters the balance of the immune response to become more suppressive (35), which could impair antiviral immune responses.

Studies have demonstrated that glutamine has antiviral activity against the herpes virus $(8,9)$. Following infection with the herpes simplex virus, glutamine-treated mice (intraperitoneal injection of $8 \mathrm{mg}$ of glutamine twice daily) were shown to have lower levels of virus, higher numbers of active CD4 and $\mathrm{CD} 8$ cells in the spleen, and increased levels of IFN- $\gamma$ in vaginal fluid at 2 and 4 days post-infection, which was associated with an improvement in the clinical signs of viral infection (8). By contrast, glutamine depletion increased the replication of herpes virus (ICP0-null mutant) in cell culture in vitro (9).

A recent study used advanced bioinformatics to identify existing therapeutic options for patients with COVID-19 (131). Two computational approaches were used to identify therapeutic agents already approved by the Food and Drug Administration (FDA) that could prevent SARS-CoV-2 from entering cells via ACE2 or TMPRSS2 enzymes and that could mitigate the gene expression patterns stimulated by coronavirus. Glutathione and its precursor glutamine were ranked high by two different methods, suggesting that both justify further investigation of their potential effects against SARS-CoV-2 (131).

Clinical studies. Low plasma glutamine levels are associated with a poor clinical outcome in intensive care unit patients (132). Following trauma and surgery, there is a marked reduction in plasma and muscle glutamine concentrations and excessive differentiation of $\mathrm{T}$ cells towards a type 2 response. These changes contribute to the state of immunosuppression and greater susceptibility to infectious complications, such as pneumonia, sepsis and bacteremia. It has been observed that the administration of enteral nutrition enriched with glutamine in patients with severe trauma increases the plasma concentrations of the amino acid and reduces the incidence of infectious complications, in addition to improving a variety of immunological parameters (133-138).

A clinical study investigated the effects of enteral nutrition enriched with glutamine compared to a control isocaloric enteral diet on the responses of $\mathrm{T}$ lymphocytes during the first 
2 weeks after severe traumatic injuries in 28 patients (injury severity score $>20$ ) (138). A total of 17 healthy volunteers were used as controls. On the first day, it was observed that $\mathrm{T}$ lymphocytes isolated from trauma patients, compared to healthy individuals, exhibited a low IFN- $\gamma$ production following stimulation with phytohemagglutinin (PHA) in vitro. After 2 weeks, glutamine nutrition significantly augmented the production of IFN- $\gamma$, in addition to preventing the decrease in IL-4 production by $\mathrm{T}$ lymphocytes stimulated in vitro. In conclusion, trauma caused the suppression of the cellular immune response, while glutamine supported the restoration of the lymphocyte response capacity by increasing IFN- $\gamma$ production and maintaining normal IL-4 production (138).

Finally, a Cochrane systematic review and meta-analysis of 57 clinical trials evaluated the effect of glutamine supplementation in a total of 4,671 adult patients with serious diseases or undergoing major surgery. The results revealed that the risk of infectious complications in subjects who received glutamine was $21 \%$ lower (RR, $0.79 ; 95 \% \mathrm{CI}, 0.71$ to 0.87 ; $<<0.00001$ ) than that in patients who did not receive glutamine. In addition, glutamine supplementation reduced the mean duration of hospitalization and the mean duration of mechanical ventilation by $3.46(95 \% \mathrm{CI},-4.61$ to $-2.32 ; \mathrm{P}<0.0001)$ and 0.69 (95\% CI, -1.37 to $-0.02 ; \mathrm{P}=0.04$ ) days, respectively (139).

\section{Conclusion}

With the advancement of the COVID-19 outbreak, there is an urgent need for the identificsation of strategies with which to combat SARS-CoV-2 infection. Immunotherapy with OncoTherad has been found to be safe and effective in the treatment of NMIBC by increasing the signaling associated with IFNs, cytokines that play essential functions in the activation of the immune system and antiviral responses. Taken together, the available evidence indicates that zinc, vitamin D and glutamine are essential in antiviral defenses, with an emphasis on the participation of these nutrients in IFN signaling, suggesting an adjuvant and synergistic therapeutic potential with OncoTherad in modulating immune function in the treatment of COVID-19 (Fig. 1). Thus, the possible beneficial role in this viral infection justifies the need for preclinical and clinical studies to evaluate the combination of these compounds and standardize the dosages that could provide greater benefits to patients.

\section{Acknowledgements}

The authors would like to thank Ms. Paula Mitie Hirata from Kilyos Nutrition for providing technical assistance with the editing of the figure.

\section{Funding}

The present study was supported by Coordenação de Aperfeiçoamento de Pessoal de Nível Superior (CAPES) (313152/2018-7) to WJF.

\section{Availability of data and materials}

Not applicable.

\section{Authors' contributions}

JJN contributed to the study concept and critically reviewed the article. ARV contributed to the design of the manuscript and figure preparation and edition. JJN, ARV, ACRS and WJF contributed to literature review and drafted the manuscript. All authors gave the final approval for all aspects of the work, agree to be fully accountable for ensuring the integrity and accuracy of the work, and read and approved the final manuscript.

\section{Ethics approval and consent to participate}

Not applicable.

\section{Patient consent for publication}

Not applicable.

\section{Competing interests}

The authors declare that they have no competing interests.

\section{References}

1. Zhou P, Yang XL, Wang XG, Hu B, Zhang L, Zhang W, Si HR, Zhu Y, Li B, Huang CL, et al: A pneumonia outbreak associated with a new coronavirus of probable bat origin. Nature 579: 270-273, 2020.

2. Gorbalenya AE, Baker SC, Baric RS, de Groot RJ, Drosten C, Gulyaeva AA, Haagmans BL, Lauber CL, Leontovich AM, Neuman BW, et al: Severe acute respiratory syndrome-related coronavirus: The species and its viruses-A statement of the Coronavirus Study Group. Microbiology, 2020.

3. Cucinotta D and Vanelli M: WHO declares COVID-19 a pandemic. Acta Biomed 91: 157-160, 2020.

4. Shang J, Wan Y, Luo C, Ye G, Geng Q, Auerbach A and Li F: Cell entry mechanisms of SARS-CoV-2. Proc Natl Acad Sci USA 117: 11727-11734, 2020.

5. Nitulescu GM, Paunescu H, Moschos SA, Petrakis D, Nitulescu G, Ion GND, Spandidos DA, Nikolouzakis TK, Drakoulis N and Tsatsakis A: Comprehensive analysis of drugs to treat SARSCoV2 infection: Mechanistic insights into current COVID19 therapies (Review). Int J Mol Med 46: 467-488, 2020.

6. Read SA, Obeid S, Ahlenstiel C and Ahlenstiel G: The role of zinc in antiviral immunity. Adv Nutr 10: 696-710, 2019.

7. Teymoori-Rad M, Shokri F, Salimi V and Marashi SM: The interplay between vitamin D and viral infections. Rev Med Virol 29: e2032, 2019.

8. Uyangaa E, Lee HK and Eo SK: Glutamine and leucine provide enhanced protective immunity against mucosal infection with herpes simplex virus type 1. Immune Netw 12: 196-206, 2012.

9. Bringhurst RM, Dominguez AA and Schaffer PA: Glutamine deprivation causes enhanced plating efficiency of a herpes simplex virus type 1 ICP0-null mutant. J Virol 82: 11472-11475, 2008.

10. Arvinte C, Singh M and Marik PE: Serum levels of vitamin C and vitamin D in a cohort of critically ill COVID-19 patients of a North American Community Hospital Intensive Care Unit in May 2020: A pilot study. Med Drug Discov 8: 100064, 2020.

11. Alexander J, Tinkov A, Strand TA, Alehagen U, Skalny A and Aaseth J: Early nutritional interventions with zinc, selenium and vitamin $\mathrm{D}$ for raising anti-viral resistance against progressive COVID-19. Nutrients 12: 2358, 2020.

12. Bauer SR, Kapoor A, Rath M and Thomas SA: What is the role of supplementation with ascorbic acid, zinc, vitamin D, or N-acetylcysteine for prevention or treatment of COVID-19? Cleve Clin J Med: Jun 8, 2020 (Epub ahead of print).

13. Benskin LL: A basic review of the preliminary evidence that COVID-19 risk and severity is increased in vitamin D deficiency. Front Public Health 8: 513, 2020.

14. Brewer J, Gomez Marti JL and Brufsky A: Potential interventions for SARS-CoV-2 infections: Zinc showing promise. J Med Virol: Sep 17, 2020 (Epub ahead of print). 
15. Calder PC, Carr AC, Gombart AF and Eggersdorfer M: Optimal nutritional status for a well-functioning immune system is an important factor to protect against viral infections. Nutrients 12: 1181,2020

16. Chakhtoura M, Napoli N and El Hajj Fuleihan G: Commentary: Myths and facts on vitamin D amidst the COVID-19 pandemic. Metabolism 109: 154276, 2020.

17. Durán $\mathrm{N}$ and Fávaro WJ: Immunomodulators acting on covid-19: Actual knowledge and perspectives. J Appl Microb Res 3: 37-44, 2020.

18. Ebadi $\mathrm{M}$ and Montano-Loza AJ: Perspective: Improving vitamin D status in the management of COVID-19. Eur J Clin Nutr 74: 856-859, 2020.

19. Ferrara F, De Rosa F and Vitiello A: The central role of clinical nutrition in COVID-19 patients during and after hospitalization in intensive care unit. SN Compr Clin Med 1-5, 2020.

20. Grant WB, Lahore H, McDonnell SL, Baggerly CA, French CB Aliano JL and Bhattoa HP: Evidence that vitamin D supplementation could reduce risk of influenza and COVID-19 infections and deaths. Nutrients 12: 988, 2020.

21. Jovic TH, Ali SR, Ibrahim N, Jessop ZM, Tarassoli SP, Dobbs TD, Holford P, Thornton CA and Whitaker IS: Could vitamins help in the fight against COVID-19? Nutrients 12: 2550, 2020.

22. Siuka D, Pfeifer M and Pinter B: Vitamin D supplementation during the COVID-19 pandemic. Mayo Clin Proc 95: 1804-1805, 2020.

23. Skalny AV, Rink L, Ajsuvakova OP, Aschner M, Gritsenko VA, Alekseenko SI, Svistunov AA, Petrakis D, Spandidos DA, Aaseth J, et al: Zinc and respiratory tract infections: Perspectives for COVID19 (Review). Int J Mol Med 46: 17-26, 2020.

24. Xu Y, Baylink DJ, Chen CS, Reeves ME, Xiao J, Lacy C, Lau E and $\mathrm{Cao} \mathrm{H}$ : The importance of vitamin $\mathrm{d}$ metabolism as a potential prophylactic, immunoregulatory and neuroprotective treatment for COVID-19. J Transl Med 18: 322, 2020.

25. Weir EK, Thenappan T, Bhargava $M$ and Chen Y: Does vitamin D deficiency increase the severity of COVID-19? Clin Med (Lond) 20: e107-e108, 2020.

26. Zhang J, McCullough PA and Tecson KM: Vitamin D deficiency in association with endothelial dysfunction: Implications for patients with COVID-19. Rev Cardiovasc Med 21: 339-344, 2020.

27. Bergman P: The link between vitamin D and COVID-19: Distinguishing facts from fiction. J Intern Med: Jul 11, 2020 (Epub ahead of print)

28. Totura AL and Bavari S: Broad-spectrum coronavirus antiviral drug discovery. Expert Opin Drug Discov 14: 397-412, 2019.

29. Berg K, Bolt G, Andersen H and Owen TC: Zinc potentiates the antiviral action of human IFN-alpha tenfold. J Interferon Cytokine Res 21: 471-474, 2001.

30. Foster M and Samman S: Zinc and regulation of inflammatory cytokines: Implications for cardiometabolic disease. Nutrients 4 : 676-694, 2012

31. Cakman I, Kirchner H and Rink L: Zinc supplementation reconstitutes the production of interferon-alpha by leukocytes from elderly persons. J Interferon Cytokine Res 17: 469-472, 1997.

32. Fabri M, Stenger S, Shin DM, Yuk JM, Liu PT, Realegeno S, Lee HM, Krutzik SR, Schenk M, Sieling PA, et al: Vitamin D is required for IFN-gamma-mediated antimicrobial activity of human macrophages. Sci Transl Med 3: 104ra102, 2011.

33. Carr EL, Kelman A, Wu GS, Gopaul R, Senkevitch E, Aghvanyan A, Turay AM and Frauwirth KA: Glutamine uptake and metabolism are coordinately regulated by ERK/MAPK during T lymphocyte activation. J Immunol 185: 1037-1044, 2010.

34. Hörig H, Spagnoli GC, Filgueira L, Babst R, Gallati H, Harder F, Juretic $A$ and Heberer M: Exogenous glutamine requirement is confined to late events of T cell activation. J Cell Biochem 53: 343-351, 1993

35. Klysz D, Tai X, Robert PA, Craveiro M, Cretenet G, Oburoglu L, Mongellaz C, Floess S, Fritz V, Matias MI, et al: Glutamine-dependent alpha-ketoglutarate production regulates the balance between $\mathrm{T}$ helper 1 cell and regulatory $\mathrm{T}$ cell generation. Sci Signal 8: ra97, 2015.

36. Fávaro WJ, Iantas SR, Gonçalves JM, Dias QC, Reis IB, Billis A, Duran $\mathrm{N}$ and Alonso JC: Role of OncoTherad immunotherapy in the regulation of toll-like receptors-mediated immune system and RANK/RANKL signaling: New therapeutic perspective for non-muscle invasive bladder cancer. J Clin Oncol 37: e16004, 2019.
37. Durán N, Dias QC and Fávaro WJ: OncoTherad: A new nanobiological response modifier, its toxicological and anticancer activities. J Phys Conf Ser: Oct 2, 2019 (Epub ahead of print). doi: 10.1088/1742-6596/1323/1/012018.

38. Fávaro W and Durán N: Process of obtaining a nanostructured complex (CFI-1), associated to nanostructured CFI-1 with a protein (MRB-CFI-1) and its use. Patent BR1020170127680. Issued June 14, 2017.

39. Challem JJ: Toward a new definition of essential nutrients: Is it now time for a third 'vitamin' paradigm? Med Hypotheses 52: 417-422, 1999 .

40. Greiller CL and Martineau AR: Modulation of the immune response to respiratory viruses by vitamin D. Nutrients 7 : 4240-4270, 2015

41. Platanias LC: Mechanisms of type-I- and type-II-interferon-mediated signalling. Nat Rev Immunol 5: 375-386, 2005.

42. Le Page C, Génin P, Baines MG and Hiscott J: Interferon activation and innate immunity. Rev Immunogenet 2: 374-386, 2000.

43. O'Brien TR, Thomas DL, Jackson SS, Prokunina-Olsson L, Donnelly RP and Hartmann R: Weak induction of interferon expression by SARS-CoV-2 supports clinical trials of interferon lambda to treat early COVID-19. Clin Infect Dis 71: 1410-1412, 2020.

44. Benveniste EN and Qin H: Type I interferons as anti-inflammatory mediators. Sci STKE 2007: pe70, 2007.

45. Karimi Y, Giles EC, Vahedi F, Chew MV, Nham T, Loukov D, Lee AJ, Bowdish DM and Ashkar AA: IFN-beta signalling regulates RAW 264.7 macrophage activation, cytokine production, and killing activity. Innate Immun 26: 172-182, 2020.

46. Billiau A: Anti-inflammatory properties of Type I interferons. Antiviral Res 71: 108-116, 2006.

47. González-Navajas JM, Lee J, David M and Raz E: Immunomodulatory functions of type I interferons. Nat Rev Immunol 12: $125-135,2012$

48. Guarda G, Braun M, Staehli F, Tardivel A, Mattmann C, Förster I, Farlik M, Decker T, Du Pasquier RA, Romero P and Tschopp J: Type I interferon inhibits interleukin-1 production and inflammasome activation. Immunity 34: 213-223, 2011.

49. Arimori Y, Nakamura R, Yamada H, Shibata K, Maeda N, Kase T and Yoshikai Y: Type I interferon limits influenza virus-induced acute lung injury by regulation of excessive inflammation in mice. Antiviral Res 99: 230-237, 2013.

50. Doherty PC, Turner SJ, Webby RG and Thomas PG: Influenza and the challenge for immunology. Nat Immunol 7: 449-455, 2006.

51. Maines TR, Szretter KJ, Perrone L, Belser JA, Bright RA, Zeng H, Tumpey TM and Katz JM: Pathogenesis of emerging avian influenza viruses in mammals and the host innate immune response. Immunol Rev 225: 68-84, 2008.

52. Taubenberger JK and Morens DM: The pathology of influenza virus infections. Annu Rev Pathol 3: 499-522, 2008.

53. Li X, Geng M, Peng Y, Meng L and Lu S: Molecular immune pathogenesis and diagnosis of COVID-19. J Pharm Anal 10: 102-108, 2020.

54. Huang C, Wang Y, Li X, Ren L, Zhao J, Hu Y, Zhang L, Fan G, $\mathrm{Xu} \mathrm{J}, \mathrm{Gu} \mathrm{X}$, et al: Clinical features of patients infected with 2019 novel coronavirus in Wuhan, China. Lancet 395: 497-506, 2020.

55. Xu Z, Shi L, Wang Y, Zhang J, Huang L, Zhang C, Liu S, Zhao P, Liu H, Zhu L, et al: Pathological findings of COVID-19 associated with acute respiratory distress syndrome. Lancet Respir Med 8: 420-422, 2020.

56. Gralinski LE and Menachery VD: Return of the coronavirus: 2019-nCoV. Viruses 12: 135, 2020.

57. Xu J, Zhao S, Teng T, Abdalla AE, Zhu W, Xie L, Wang Y and Guo X: Systematic comparison of two animal-to-human transmitted human coronaviruses: SARS-CoV-2 and SARS-CoV. Viruses 12: 244, 2020

58. Sarzi-Puttini P, Giorgi V, Sirotti S, Marotto D, Ardizzone S, Rizzardini G, Antinori S and Galli M: COVID-19, cytokines and immunosuppression: What can we learn from severe acute respiratory syndrome? Clin Exp Rheumatol 38: 337-342, 2020.

59. Kindler E, Thiel V and Weber F: Interaction of SARS and MERS coronaviruses with the antiviral interferon response. Adv Virus Res 96: 219-243, 2016.

60. Perlman S and Dandekar AA: Immunopathogenesis of coronavirus infections: Implications for SARS. Nat Rev Immunol 5: 917-927, 2005

61. Pedersen SF and Ho YC: SARS-CoV-2: A storm is raging. J Clin Invest 130: 2202-2205, 2020 
62. Chu H, Chan JF, Wang Y, Yuen TT, Chai Y, Hou Y, Shuai H, Yang D, Hu B, Huang X, et al: Comparative replication and immune activation profiles of SARS-CoV-2 and SARS-CoV in human lungs: An ex vivo study with implications for the pathogenesis of COVID-19. Clin Infect Dis 71: 1400-1409, 2020.

63. Li SF, Gong MJ, Zhao FR, Shao JJ, Xie YL, Zhang YG and Chang HY: Type I interferons: Distinct biological activities and current applications for viral infection. Cell Physiol Biochem 51: 2377-2396, 2018.

64. Haagmans BL, Kuiken T, Martina BE, Fouchier RA, Rimmelzwaan GF, van Amerongen G, van Riel D, de Jong T, Itamura $\mathrm{S}$, Chan $\mathrm{KH}$, et al: Pegylated interferon-alpha protects type 1 pneumocytes against SARS coronavirus infection in macaques. Nat Med 10: 290-293, 2004.

65. Cinatl J, Morgenstern B, Bauer G, Chandra P, Rabenau H and Doerr HW: Treatment of SARS with human interferons. Lancet 362: 293-294, 2003.

66. Falzarano D, de Wit E, Rasmussen AL, Feldmann F, Okumura A, Scott DP, Brining D, Bushmaker T, Martellaro C, Baseler L, et al: Treatment with interferon- $\alpha 2 b$ and ribavirin improves outcome in MERS-CoV-infected rhesus macaques. Nat Med 19: 1313-1317, 2013.

67. Ströher U, DiCaro A, Li Y, Strong JE, Aoki F, Plummer F, Jones SM and Feldmann $\mathrm{H}$ : Severe acute respiratory syndrome-related coronavirus is inhibited by interferon-alpha. J Infect Dis 189: 1164-1167, 2004.

68. Channappanavar R, Fehr AR, Zheng J, Wohlford-Lenane C, Abrahante JE, Mack M, Sompallae R, McCray PB Jr, Meyerholz DK and Perlman S: IFN-I response timing relative to virus replication determines MERS coronavirus infection outcomes. J Clin Invest 130: 3625-3639, 2019.

69. Hensley LE, Fritz LE, Jahrling PB, Karp CL, Huggins JW and Geisbert TW: Interferon-beta la and SARS coronavirus replication. Emerg Infect Dis 10: 317-319, 2004

70. Turner RB, Felton A, Kosak K, Kelsey DK and Meschievitz CK Prevention of experimental coronavirus colds with intranasal alpha-2b interferon. J Infect Dis 154: 443-447, 1986.

71. Falzarano D, de Wit E, Martellaro C, Callison J, Munster VJ and Feldmann H: Inhibition of novel beta coronavirus replication by a combination of interferon-alpha2b and ribavirin. Sci Rep 3: 1686,2013

72. Thiel V and Weber F: Interferon and cytokine responses to SARS-coronavirus infection. Cytokine Growth Factor Rev 19: 121-132, 2008

73. Sainz B Jr, Mossel EC, Peters CJ and Garry RF: Interferon-beta and interferon-gamma synergistically inhibit the replication of severe acute respiratory syndrome-associated coronavirus (SARS-CoV). Virology 329: 11-17, 2004.

74. Mossel EC, Sainz B Jr, Garry RF and Peters CJ: Synergistic inhibition of SARS-coronavirus replication by type I and type II IFN. Adv Exp Med Biol 581: 503-506, 2006.

75. Yoshikawa T, Hill TE, Yoshikawa N, Popov VL, Galindo CL, Garner HR, Peters CJ and Tseng CT: Dynamic innate immune responses of human bronchial epithelial cells to severe acute respiratory syndrome-associated coronavirus infection. PLoS One 5: e8729, 2010

76. Larkin J, Jin L, Farmen M, Venable D, Huang Y, Tan SL and Glass JI: Synergistic antiviral activity of human interferon combinations in the hepatitis $\mathrm{C}$ virus replicon system. $\mathrm{J}$ Interferon Cytokine Res 23: 247-257, 2003.

77. Li G and De Clercq E: Therapeutic options for the 2019 novel coronavirus (2019-nCoV). Nat Rev Drug Discov 19: 149-150, 2020.

78. Fávaro WJ, Iantas SR, Gonçalves JM, Socca EAR, Durán N and Billis A: Single-arm phase I/II study of the safety and efficacy of OncoTherad immunomodulator in patients BCG-refractory or relapsed non-muscle invasive bladder cancer. J Clin Oncol 37 e16000, 2019.

79. Böckelmann PK, Tizziani SH, Durán N and Fávaro WJ: New therapeutic perspective for bladder cancer in dogs: Toxicological and clinical effects of oncotherad nanostructured immunotherapy. J Phys Conf Ser 1323: 012022, 2019.

80. Fávaro WJ and Caballero NE: A method for producing a nanostructured complex (cfi-1), a protein-associated nanostructured complex (mrb-cfi-1) and use. US Patent 20200156951. Filed June 14, 2018; issued May 21, 2020.

81. Fávaro WJ and Caballero NED: A method for producing a nanostructured complex (cfi-1), a protein-associated nanostructured complex (mrb-cfi-1) And use. Patent WO2018227261. Filed June 13,2018; issued December 19,2018.
82. Alonso JCC, Reis IB, Goncalves JM, Sasaki BR, Cintra AA, DuranN,Billis A andFávaro WJ:Oncotheradimmunotherapy elicits promising responses in Bacillus Calmette-Guérin-unresponsive non-muscle invasive bladder cancer: Results from phase I/ II study. J Clin Oncol 38: e17048, 2020.

83. Totura AL, Whitmore A, Agnihothram S, Schäfer A, Katze MG, Heise MT and Baric RS: Toll-like receptor 3 signaling via TRIF contributes to a protective innate immune response to severe acute respiratory syndrome coronavirus infection. mBio 6: e00638-00615, 2015.

84. Delafiori J, Alonso JCC, Santos LA, Oliveira DN, Navarro LC, Brandt Busanello EN, Sales GM, Oliveira AN, Rocha AR, Durán N, et al: A 78-year old urothelial cancer patient with faster recovery from COVID-19: Potential benefit from adjuvant active immunotherapy. SSRN: Jun 4, 2020 (Epub ahead of print).

85. Chen J, Qi T, Liu L, Ling Y, Qian Z, Li T, Li F, Xu Q, Zhang Y, $\mathrm{Xu} \mathrm{S}$, et al: Clinical progression of patients with COVID-19 in Shanghai, China. J Infect 80: e1-e6, 2020.

86. Wei Z, Burwinkel M, Palissa C, Ephraim E and Schmidt MF: Antiviral activity of zinc salts against transmissible gastroenteritis virus in vitro. Vet Microbiol 160: 468-472, 2012.

87. Korant BD, Kauer JC and Butterworth BE: Zinc ions inhibit replication of rhinoviruses. Nature 248: 588-590, 1974.

88. Suara RO and Crowe JE Jr: Effect of zinc salts on respiratory syncytial virus replication. Antimicrob Agents Chemother 48 783-790, 2004.

89. te Velthuis AJ, van den Worm SH, Sims AC, Baric RS, Snijder EJ and van Hemert MJ: $\mathrm{Zn}(2+)$ inhibits coronavirus and arterivirus RNA polymerase activity in vitro and zinc ionophores block the replication of these viruses in cell culture. PLoS Pathog 6: e1001176, 2010

90. Kaushik N, Anang S, Ganti KP and Surjit M: Zinc: A potential antiviral against Hepatitis E virus infection? DNA Cell Biol 37: 593-599, 2018

91. Aydemir TB, Liuzzi JP, McClellan S and Cousins RJ: Zinc transporter ZIP8 (SLC39A8) and zinc influence IFN-gamma expression in activated human $\mathrm{T}$ cells. J Leukoc Biol 86: 337-348, 2009.

92. Bao S and Knoell DL: Zinc modulates cytokine-induced lung epithelial cell barrier permeability. Am J Physiol Lung Cell Mol Physiol 291: L1132-L1141, 2006.

93. Reiber C, Brieger A, Engelhardt G, Hebel S, Rink L and Haase H: Zinc chelation decreases IFN- $\beta$-induced STAT1 upregulation and iNOS expression in RAW 264.7 macrophages. J Trace Elem Med Biol 44: 76-82, 2017.

94. Huang IC, Bailey CC, Weyer JL, Radoshitzky SR, Becker MM, Chiang JJ, Brass AL, Ahmed AA, Chi X, Dong L, et al: Distinct patterns of IFITM-mediated restriction of filoviruses, SARS coronavirus, and influenza A virus. PLoS Pathog 7: e1001258, 2011.

95. Fu B, Wang L, Li S and Dorf ME: ZMPSTE24 defends against influenza and other pathogenic viruses. J Exp Med 214: 919-929, 2017

96. Li S, Fu B, Wang L and Dorf ME: ZMPSTE24 is downstream effector of interferon-induced transmembrane antiviral activity. DNA Cell Biol 36: 513-517, 2017.

97. Brieger A, Rink L and Haase H: Differential regulation of TLR-dependent MyD88 and TRIF signaling pathways by free zinc ions. J Immunol 191: 1808-1817, 2013.

98. Newton K and Dixit VM: Signaling in innate immunity and inflammation. Cold Spring Harb Perspect Biol 4: a006049, 2012

99. Costarelli L, Giacconi R, Malavolta M, Basso A, Piacenza F, DeMartiis M, Giannandrea E, Renieri C, Busco F, Galeazzi R and Mocchegiani E: Effects of zinc-fortified drinking skim milk (as functional food) on cytokine release and thymic hormone activity in very old persons: A pilot study. Age (Dordr) 36: 9656 , 2014.

100. Kahmann L, Uciechowski P, Warmuth S, Plümäkers B, Gressner AM, Malavolta M, Mocchegiani E and Rink L: Zinc supplementation in the elderly reduces spontaneous inflammatory cytokine release and restores $\mathrm{T}$ cell functions. Rejuvenation Res 11: 227-237, 2008.

101. ILSI Brasil International Life Sciences Institute do Brasil: Vitamina D. Funcões Plenamente Reconhecidas de Nutrientes, Vol. 2. Brazil, p43, 2018

102. Pludowski P, Holick MF, Pilz S, Wagner CL, Hollis BW, Grant WB, Shoenfeld Y, Lerchbaum E, Llewellyn DJ, Kienreich K and Soni M: Vitamin D effects on musculoskeletal health, immunity, autoimmunity, cardiovascular disease, cancer, fertility, pregnancy, dementia and mortality-a review of recent evidence. Autoimmun Rev 12: 976-989, 2013. 
103. Catarino AM, Claro C and Viana I: Vitamin D-current perspectives. J Portug Soc Dermatol Venereol 74: 345-353, 2016

104. White JH: Regulation of intracrine production of 1,25-dihydroxyvitamin $\mathrm{D}$ and its role in innate immune defense against infection. Arch Biochem Biophys 523: 58-63, 2012

105. Evans KN, Taylor H, Zehnder D, Kilby MD, Bulmer JN, Shah F, Adams JS and Hewison M: Increased expression of 25-hydroxyvitamin D-1alpha-hydroxylase in dysgerminomas: A novel form of humoral hypercalcemia of malignancy. Am J Pathol 165: 807-813, 2004

106. Stoffels K, Overbergh L, Giulietti A, Verlinden L, Bouillon R and Mathieu C: Immune regulation of 25-hydroxyvitamin-D3-1alpha-hydroxylase in human monocytes. J Bone Miner Res 21: 37-47, 2006.

107. Hewison M, Freeman L, Hughes SV, Evans KN, Bland R, Eliopoulos AG, Kilby MD, Moss PA and Chakraverty R: Differential regulation of vitamin $\mathrm{D}$ receptor and its ligand in human monocyte-derived dendritic cells. J Immunol 170 : $5382-5390,2003$

108. Fritsche J,Mondal K, Ehrnsperger A, Andreesen R and Kreutz M Regulation of 25-hydroxyvitamin D3-1 alpha-hydroxylase and production of 1 alpha,25-dihydroxyvitamin D3 by human dendritic cells. Blood 102: 3314-3316, 2003.

109. Enioutina EY, Bareyan D and Daynes RA: TLR-induced local metabolism of vitamin D3 plays an important role in the diversification of adaptive immune responses. J Immunol 182 4296-4305, 2009.

110. Enioutina EY, Bareyan D and Daynes RA: TLR ligands that stimulate the metabolism of vitamin D3 in activated murine dendritic cells can function as effective mucosal adjuvants to subcutaneously administered vaccines. Vaccine 26: 601-613, 2008.

111. Hansdottir S, Monick MM, Hinde SL, Lovan N, Look DC and Hunninghake GW: Respiratory epithelial cells convert inactive vitamin D to its active form: Potential effects on host defense. J Immunol 181: 7090-7099, 2008.

112. Overbergh L, Stoffels K, Waer M, Verstuyf A, Bouillon R and Mathieu C: Immune regulation of 25-hydroxyvitamin D-1alpha-hydroxylase in human monocytic THP1 cells: Mechanisms of interferon-gamma-mediated induction. J Clin Endocrinol Metab 91: 3566-3574, 2006.

113. Rhodes JM, Subramanian S, Laird E, Griffin G and Kenny RA: Perspective: Vitamin D deficiency and COVID-19 severity-plausibly linked by latitude, ethnicity, impacts on cytokines, ACE2 and thrombosis. J Intern Med: Jul 2, 2020 (Epub ahead of print)

114. Yan T, Xiao R and Lin G: Angiotensin-converting enzyme 2 in severe acute respiratory syndrome coronavirus and SARS-CoV-2: A double-edged sword? FASEB J 34: 6017-6026, 2020.

115. Imai Y, Kuba K, Rao S, Huan Y, Guo F, Guan B, Yang P, Sarao R, Wada T, Leong-Poi $\mathrm{H}$, et al: Angiotensin-converting enzyme 2 protects from severe acute lung failure. Nature 436 $112-116,2005$

116. Kuba K, Imai Y, Rao S, Gao H, Guo F, Guan B, Huan Y, Yang P, Zhang Y, Deng W, et al: A crucial role of angiotensin converting enzyme 2 (ACE2) in SARS coronavirus-induced lung injury. Nat Med 11: 875-879, 2005.

117. Kumar D, Gupta P and Banerjee D: Letter: Does vitamin D have a potential role against COVID-19? Aliment Pharmacol Ther 52: 409-411, 2020.

118. Musavi H, Abazari O, Barartabar Z, Kalaki-Jouybari F, Hemmati-Dinarvand M, Esmaeili $\mathrm{P}$ and Mahjoub S: The benefits of vitamin D in the COVID-19 pandemic: Biochemical and immunological mechanisms. Arch Physiol Biochem: Oct 8 , 2020 (Epub ahead of print).

119. Malek Mahdavi A: A brief review of interplay between vitamin $D$ and angiotensin-converting enzyme 2: Implications for a potential treatment for COVID-19. Rev Med Virol 30: e2119, 2020

120. Omori-Mizuno Y, Nakayama N, Inao M, Funyu J, Asabe S, Tomita K, Nishikawa K, Hosoda Y, Tanaka M, Hashimoto Y, et al: Randomized study comparing vitamin D3 and 1alpha-Hydroxyvitamin D3 in combination with pegylated interferon/ribavirin therapy for chronic hepatitis $\mathrm{C}$. J Gastroenterol Hepatol 30: 1384-1390, 2015.

121. Abu-Mouch S, Fireman Z, Jarchovsky J, Zeina AR and Assy N: Vitamin D supplementation improves sustained virologic response in chronic hepatitis $\mathrm{C}$ (genotype 1)-naive patients. World J Gastroenterol 17: 5184-5190, 2011.

122. Nimer A and Mouch A: Vitamin D improves viral response in hepatitis C genotype 2-3 naive patients. World J Gastroenterol 18: $800-805,2012$.
123. Yokoyama S, Takahashi S, Kawakami Y, Hayes CN, Kohno H, Kohno H, Tsuji K, Aisaka Y, Kira S, Yamashina K, et al: Effect of vitamin D supplementation on pegylated interferon/ribavirin therapy for chronic hepatitis $\mathrm{C}$ genotype $1 \mathrm{~b}$ : A randomized controlled trial. J Viral Hepat 21: 348-356, 2014.

124. Petta S, Cammà C, Scazzone $C$, Tripodo $C$, Di Marco V, Bono A, Cabibi D, Licata G, Porcasi R, Marchesini G and Craxí A: Low vitamin D serum level is related to severe fibrosis and low responsiveness to interferon-based therapy in genotype 1 chronic hepatitis C. Hepatology 51: 1158-1167, 2010.

125. Behera MK, Shukla SK, Dixit VK, Nath P, Abhilash VB, Asati PK and Jain AK: Effect of vitamin D supplementation on sustained virological response in genotype $1 / 4$ chronic hepatitis $\mathrm{C}$ treatment-naive patients from India. Indian J Med Res 148: 200-206, 2018

126. Wang K, Hoshino Y, Dowdell K, Bosch-Marce M, Myers TG, Sarmiento M, Pesnicak L, Krause PR and Cohen JI: Glutamine supplementation suppresses herpes simplex virus reactivation. J Clin Invest 127: 2626-2630, 2017.

127. Wang R, Dillon CP, Shi LZ, Milasta S, Carter R, Finkelstein D, McCormick LL, Fitzgerald P, Chi H, Munger J and Green DR: The transcription factor Myc controls metabolic reprogramming upon T lymphocyte activation. Immunity 35: 871-882, 2011.

128. Nakaya M, Xiao Y, Zhou X, Chang JH, Chang M, Cheng X, Blonska M, Lin X and Sun SC: Inflammatory T cell responses rely on amino acid transporter ASCT2 facilitation of glutamine uptake and mTORC1 kinase activation. Immunity 40: 692-705, 2014.

129. Sinclair LV, Rolf J, Emslie E, Shi YB, Taylor PM and Cantrell DA: Control of amino-acid transport by antigen receptors coordinates the metabolic reprogramming essential for T cell differentiation. Nat Immunol 14: 500-508, 2013.

130. Chang WK, Yang KD and Shaio MF: Effect of glutamine on Th1 and Th2 cytokine responses of human peripheral blood mononuclear cells. Clin Immunol 93: 294-301, 1999.

131. Kim J, Zhang J, Cha Y, Kolitz S, Funt J, Escalante Chong R, Barrett S, Kusko R, Zeskind B and Kaufman H: Advanced bioinformatics rapidly identifies existing therapeutics for patients with coronavirus disease-2019 (COVID-19). J Transl Med 18: 257, 2020.

132. Oudemans-van Straaten HM, Bosman RJ, Treskes M, van der Spoel HJ and Zandstra DF: Plasma glutamine depletion and patient outcome in acute ICU admissions. Intensive Care Med 27: 84-90, 2001.

133. O'Mahony JB, Palder SB, Wood JJ, McIrvine A, Rodrick ML, Demling RH and Mannick JA: Depression of cellular immunity after multiple trauma in the absence of sepsis. J Trauma 24: 869-875, 1984

134. O'Sullivan ST, Lederer JA, Horgan AF, Chin DH, Mannick JA and Rodrick ML: Major injury leads to predominance of the T helper-2 lymphocyte phenotype and diminished interleukin-12 production associated with decreased resistance to infection. Ann Surg 222: 482-490; discussion 490-492, 1995.

135. Fläring UB, Rooyackers OE, Wernerman J and Hammarqvist F: Glutamine attenuates post-traumatic glutathione depletion in human muscle. Clin Sci (Lond) 104: 275-282, 2003

136. Mittendorfer B, Gore DC, Herndon DN and Wolfe RR: Accelerated glutamine synthesis in critically ill patients cannot maintain normal intramuscular free glutamine concentration. JPEN J Parenter Enteral Nutr 23: 243-252, 1999.

137. Houdijk AP, Rijnsburger ER, Jansen J, Wesdorp RI, Weiss JK McCamish MA, Teerlink T, Meuwissen SG, Haarman HJ, Thijs LG and van Leeuwen PA: Randomised trial of glutamine-enriched enteral nutrition on infectious morbidity in patients with multiple trauma. Lancet 352: 772-776, 1998.

138. Boelens PG, Houdijk AP, Fonk JC, Puyana JC, Haarman HJ, von Blomberg-van der Flier $\mathrm{ME}$ and van Leeuwen PA: Glutamine-enriched enteral nutrition increases in vitro interferon-gamma production but does not influence the in vivo specific antibody response to KLH after severe trauma. A prospective, double blind, randomized clinical study. Clin Nutr 23: 391-400, 2004.

139. Tao KM, Li XQ, Yang LQ, Yu WF, Lu ZJ, Sun YM and Wu FX: Glutamine supplementation for critically ill adults. Cochrane Database Syst Rev 2014: CD010050, 2014.

This work is licensed under a Creative Commons Attribution-NonCommercial-NoDerivatives 4.0 International (CC BY-NC-ND 4.0) License. 